\title{
Prevalence assessment of root dilaceration in permanent incisors
}

\author{
Beatriz Feitosa da Silva1', Luciana Ellen Dantas Costaㄹ ${ }^{2}$ Ricardo Villar Beltrão ${ }^{3}$, Tânia Lemos Rodrigues ${ }^{4}$, \\ Ricardo Lombardi de Farias ${ }^{5}$, Rejane Targino Soares Beltrão ${ }^{6}$
}

\begin{abstract}
Introduction: Root dilaceration is a dental anomaly characterized by an abnormal curvature of the dental root, which can cause problems during eruption and complications in the orthodontic and endodontic treatment or extraction. Objective: The aim of this study was to determine the prevalence of root dilaceration in permanent incisors in an oral radiology clinic in the city of João Pessoa / PB, Brazil. Methods: The sample consisted of 548 patients who allowed assessments of their dental radiographs, a total of 3,948 examined teeth. Each tooth was examined according to the occurrence of root dilaceration, regarding type (mild, moderate or severe), root third that it was in and direction of the root. The angle formed by the root deviation in relation to the long tooth axis was obtained by means of a diagram printed on transparent acetate, placed over the radiograph. Results: The results were analyzed with SPSS software (Statistical Package for Social Sciences) version 13.0, performing an exploratory data analysis. The prevalence of root dilaceration in the studied sample was $1.03 \%$ (41 cases), with higher incidence in males (65.8\%), being the superior lateral incisor the most affected teeth (78\%). The most prevalent type of root dilaceration was the mild one (73.1\%), occurring more in the apical third (90.2\%) and with distal direction of the root (95.1\%). Conclusion: Considering these results, it is emphasized the importance of performing a diagnostic radiographic examination prior to planning a treatment in permanent anterior teeth.
\end{abstract}

Keywords: Incisor. Tooth root. Tooth abnormalities. Dental radiograph. Prevalence.

Introdução: a dilaceração radicular é uma anomalia dentária caracterizada por uma curvatura anormal na raiz do dente que pode causar problemas na erupção e complicações durante movimentação ortodôntica, tratamento endodôntico ou exodontia. Objetivo: o objetivo do presente trabalho foi verificar a prevalência da dilaceração radicular em incisivos permanentes, em uma clínica de radiologia odontológica da cidade de João Pessoa/PB. Método: a amostra foi constituída de 548 pacientes que possibilitaram avaliações em suas radiografias dentárias, totalizando 3948 dentes examinados. Examinou-se cada dente segundo a ocorrência de dilaceração radicular, com relação ao tipo (discreta, moderada ou severa), o terço radicular em que se encontrava e a direção da raiz. A angulação formada pelo desvio da raiz em relação ao longo eixo do dente foi obtida por meio de um diagrama impresso em acetato transparente, colocado sobre a radiografia. Resultados: os resultados foram analisados no programa SPSS, efetuando-se uma análise exploratória dos dados. A prevalência da dilaceração radicular na amostra estudada foi de 1,03\% (41 casos), com maior incidência no sexo masculino (65,8\%), sendo os incisivos laterais superiores os dentes mais acometidos (78\%). O tipo de dilaceração radicular mais prevalente foi a discreta $(73,1 \%)$, ocorrendo mais no terço apical (90,2\%) e com direção distal da raiz (95,1\%). Conclusão: diante desses resultados, ressaltam-se a importância da realização prévia de um exame radiográfico de diagnóstico ao planejar um tratamento em dentes permanentes anteriores.

Palavras-chave: Incisivo. Raiz dentária. Anormalidades dentárias. Radiografia dentária. Prevalência.

${ }^{1}$ Graduated in Dentistry, UFPB.

${ }^{2}$ MSc in Pediatric and Preventive Dentistry, UFPB. Professor of Public Health, UFCG.

${ }^{3} \mathrm{PhD}$ in Radiology, UFBA. Professor of Radiology, UFPB.

${ }^{4} \mathrm{PhD}$ in Oral and Maxillofacial Surgery, UFRJ. Professor of Surgery, UFPB.

${ }^{5} \mathrm{PhD}$ in Orthodontics. Faculty of Dentistry of Araraquara. Professor of

Orthodontics, UFPB.

${ }^{6} \mathrm{PhD}$ in Orthodontics and Dental Public Health, USP. Professor of Orthodontics, UFPB.

Submitted: March 18, 2009 - Revised and accepted: March 29, 2010
How to cite this article: Silva BF, Costa LED, Beltrão RV, Rodrigues TL, Farias RL, Beltrão RTS. Prevalence assessment of root dilaceration in permanent incisors. Dental Press J Orthod. 2012 Nov-Dec;17(6):97-102.

» The author reports no commercial, proprietary or financial interest in the products or companies described in this article.

Contact address: Luciana Ellen Dantas Costa

Rua Eurico Uchoa, 100 - Bairro dos Estados - João Pessoa/PB - Brazil

CEP: 58031-150 - E-mail: ellendantascosta@yahoo.com.br 


\section{INTRODUCTION}

It is relatively common, in clinical experience, that the non-eruption of permanent incisors is due to prolonged retention of its deciduous corresponding tooth, to the absence of the permanent succeeding tooth or the installation of developmental abnormalities; which is noticed from the age of eight, in the first transitional period of the mixed dentition. ${ }^{3}$

With the exception of trauma, root dilaceration is a dental anomaly in which the tooth root presents a curvature of varied angle, caused by the displacement of the crown from the rest of the root during its early development. ${ }^{19}$ For Chohayeb, ${ }^{7}$ a root deviation can be considered root dilaceration when the angle between the root and the long axis of the tooth is equal to or greater than $20^{\circ}$.

The cause of root dilaceration is controversial, being attributed to a strong relation with the trauma in the primary dentition - as intrusive luxation or avulsion of its deciduous corresponding tooth. $3,14,17,22,29$ However, there are reports that associate to this anomaly, hereditary factors, ${ }^{19}$ the presence of cysts or tumors, ${ }^{5,8}$ supernumerary teeth ${ }^{25}$ and ectopic development of the upper incisor tooth germ, with the root following the curvature of the palate, presenting the alteration. ${ }^{15}$

Brin et $\mathrm{al}^{3}$ and Laskaris ${ }^{14}$ explained their possible theories to justify such a relation with dental trauma. Due to proximity between the deciduous root apex with the permanent germ, the occurrence of injuries during odontogenesis may cause displacement of the calcified portion of the rest of the tooth, which continues its development in this new position, creating an unusual angle. ${ }^{3,14}$

Gonçalves et $\mathrm{al}^{12}$ associated the premature loss of deciduous teeth to the local formation of a fibrotic scar which prevents normal development of the permanent tooth, the same occurs in the presence of any obstacle to normal development of tooth germ, causing a progressive angulation crown/root. ${ }^{13}$

The apical root dilaceration may affect approximately 1 to $4.9 \%$ of all permanent teeth, with a higher frequency in female patients, ${ }^{10,21,28}$ and it may, occasionally, involve deciduous teeth as a result of previous trauma due to neonatal laryngoscopy or endotracheal intubation. ${ }^{4}$
According to Silva Filho et al, ${ }^{25}$ of all permanent incisors, the upper centrals are the most affected (70.6\%) followed by the laterals (20.6\%) and lower incisors $(8.8 \%)$. While Erlich, Pereira, Panella ${ }^{10}$ when examining all permanent teeth, except the third molars, said to be the permanent upper lateral incisors the most affected, followed by the upper second premolars and lower first premolars.

The diagnosis of root dilaceration takes place, usually by radiographic examination. ${ }^{10}$ Clinically, the failed eruption of permanent incisors, especially the upper ones, leads professionals to suspect of that anomaly. ${ }^{4}$

The radiograph is essential to observe the stage of root formation and the degree of dilaceration, being important to determine the morphology and spatial position of the tooth in the bone. ${ }^{12}$ Making use of the periapical, occlusal, and panoramic radiographs or computed tomography, which provides precisely, the real location of the dental and bone structures. ${ }^{4}$

Depending on the degree of root angulation, the treatment and prognosis of teeth with root dilaceration varies. ${ }^{9,15}$ In mild cases, treatment is not necessary, however, there are cases where the tooth must be exposed surgically and orthodontically moved, and in more severe cases, due to treatment impossibility, the surgical removal followed by prosthetic rehabilitation is indicated. $6,15,20$

The studies on prevalence of root dilaceration include, mostly, all permanent teeth, ${ }^{10,16,21,28}$ not being observed studies regarding only central and lateral permanent incisors.

It is also observed that these studies ${ }^{10,16,21,28}$ generally evaluate radiographs of patients from educational institutions, which can provide a biased result, that do not correspond to reality, since the most complicated cases are usually referred to these institutions. To eliminate this bias, a oral radiology clinic in the city of João Pessoa/PB (Brazil), was selected by convenience, in order to refer epidemiological data in an untainted population, seeking detailed and real information in relation to a group of teeth.

Given the impossibility of preventing this abnormality and the need to increase the understanding and the ability of the diagnosis of dentists on the subject, this study aimed to evaluate the prevalence of root dilaceration in permanent central and lateral incisors in both maxilla and mandible. 


\section{MATERIAL AND METHODS}

In this cross-sectional, descriptive study, we obtained a sample of 3948 central and lateral permanent incisors, observed in 548 radiographs from an oral radiology clinic in the city of João Pessoa, Paraíba (Brazil), evaluated within the period from October to December, 2008.

From the evaluated radiographs, 382 were panoramic and 166 were periapical, belonging to 238 female individuals and 310 to males.

All exams were standardized, obtained by the same operator and machine. Panoramic and periapical radiographs and teleradiographs (only for the cases of labial-palatal dilaceration) that showed maximum sharpness, medium contrast and density, were included in the sample. The X-ray examinations of patients under the age of seven years and permanent incisors with less than two thirds of root formed were excluded from the sample.

The radiographs were interpreted in the dark with the aid of a magnifier ( $2 x$ magnifying capacity) on a light box with black cardboard masks, the panoramic measuring $15 \times 30 \mathrm{~cm}$ and the periapicals $2.5 \times 5.0 \mathrm{~cm}$.

Each tooth was examined for the occurrence of root dilaceration, according to Santana, Consolaro and Tavano, ${ }^{21}$ in mild $\left(20-40^{\circ}\right)$, moderate $\left(41-60^{\circ}\right)$, severe curvature degree $\left(\geq 61^{\circ}\right)$, root third in which it was present (cervical, middle or apical), and root direction (mesial, distal, buccal or lingual). The deviations greater than $20^{\circ}$ formed by the roots in relation to the long axis of the tooth were considered as dilaceration. ${ }^{7}$

To classify the dilaceration in accordance with the degree of curvature, in mild, moderate or severe, a method similar to the one by Schneider, ${ }^{24}$ and Erlich, Pereira and Panella ${ }^{10}$ was used which measured the angle formed by the midlines of the tooth long axis and the deviated segment. In this study a diagram was made on AutoCAD software (version 2006), containing the angles and indexes in

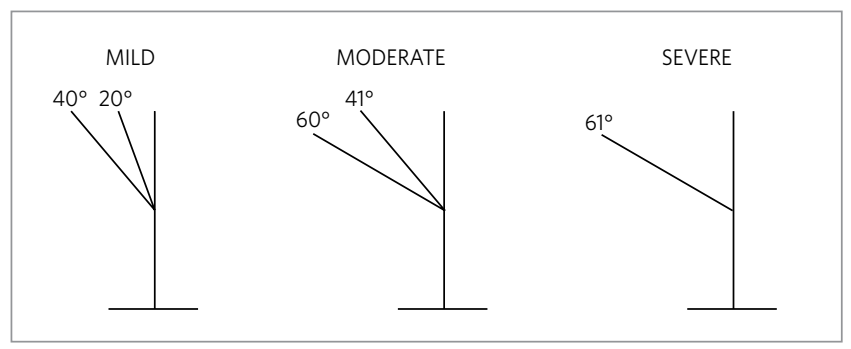

Figure 1 - Diagram showing rates - classification of dilaceration in mild, moderate or severe. Source: Santana, Consolaro and Tavano21, Schneider $^{24}$, and Erlich, Pereira and Panella. ${ }^{10}$
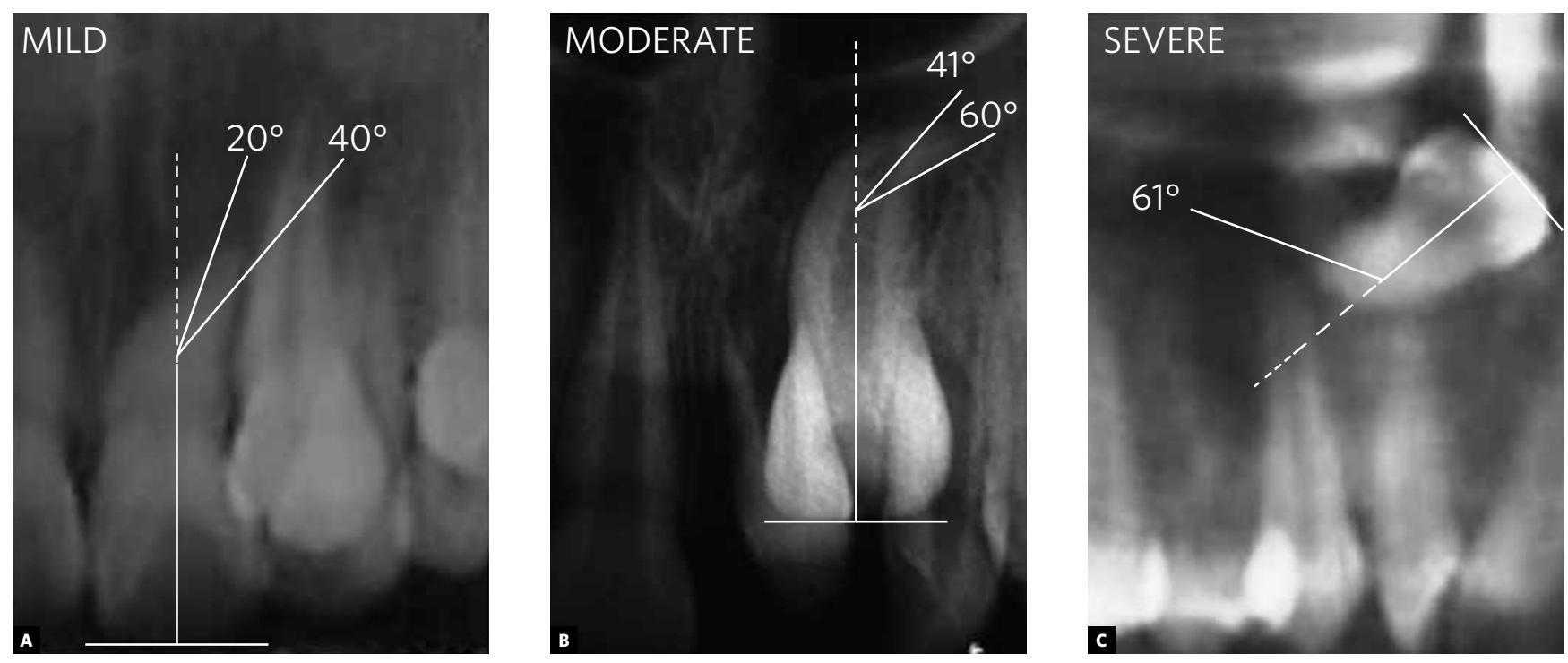

Figure 2 - Mild, moderate and severe root dilaceration type. 
transparent acetate (Fig 1). To measure the values, the radiograph was superimposed on the diagram and evaluated on the light box (Fig 2).

If the patient did not present root dilaceration, only the identification data were noted (gender and age) and number of examined teeth.

The data were classified in SPSS v. 13.0 (Statistical Package for Social Sciences) an exploratory data analysis was performed with the construction of single frequency and double entry tables, as well as statistical result graphs.

The study was previously approved by the person in charge of the oral radiology clinic and the Committee on Ethics in Research involving human beings, of the Center for Health Sciences, Federal University of Paraíba, with protocol No. 0141.

\section{RESULTS}

Five hundred and forty eight radiographs of upper central and lateral permanent incisors, aged from 7 to 77 years of age were evaluated (Fig 3). Panoramic radiographs $(69.7 \%)$ and periapical $(30.3 \%)$

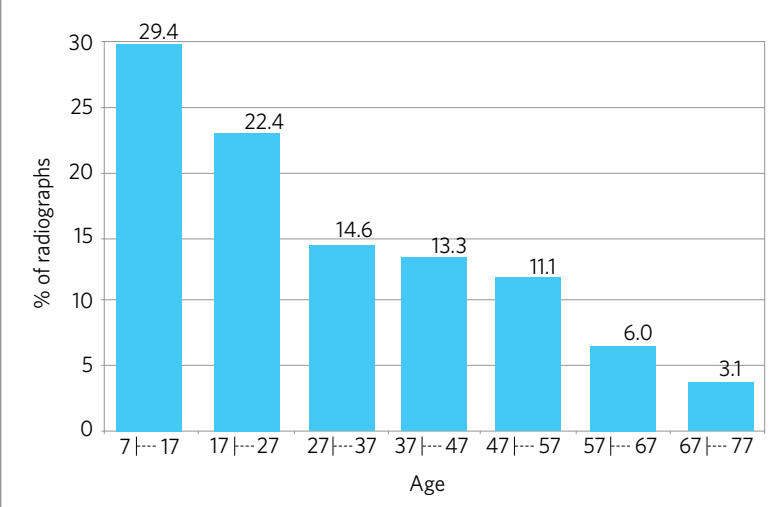

Figure 3 - Distribution of the percentage of examined radiographs according to the age of individuals. João Pessoa / PB (Brazil), 2008.

Table 1 - Prevalence of root dilaceration in permanent incisors. João Pessoa / PB (Brazil), 2008

Teeth

Number of examined teeth

Total number of dilaceration

Prevalence of dilaceration (\%)

\section{UCI LCI ULI LLI}

1001993955999

$\begin{array}{llll}2 & 1 & 32 & 6\end{array}$

$0,2 \quad 0,1 \quad 3,35 \quad 0,6$

$\mathrm{UCI}$ - upper central incisors; LCI - lower central incisors; ULI - upper lateral incisors, LLI - lower lateral incisors. belonged to $238(43.4 \%)$ female patients and 310 $(56.6 \%)$ males.

The prevalence of root dilaceration in the sample was $1.03 \%$, affecting the maxilla ( $82.9 \%)$ more than the mandible (17.1\%). The upper lateral incisors were the most affected (32-3.35\%), followed by the lower lateral incisors $(6-0.6 \%)$, upper central $(2-0.2 \%)$ and lower central $(1-0,1 \%)$ (Table 1$)$. Twenty-seven cases $(65.8 \%)$ of dilaceration in males and $14(34.2 \%)$ in females was observed.

The permanent incisors with root dilaceration presented a mild curvature in $73.1 \%$ (30) of the sample, followed by the moderate type (7 - 17.0\%) and severe $(4-9.7 \%)$. As for the root third where they were located: $90.2 \%$ (37) of dilacerations were in the apical third, $7.3 \%$ (3) in the middle third and only $1(2.4 \%)$ in the cervical third. The dilacerated roots were more frequently facing distal in $95.1 \%$ (39 teeth), only one was mesial and another one was buccal $(2.4 \%)$.

\section{DISCUSSION}

Root dilaceration is a dental anomaly of shape characterized by a change in the root or crown angulation of the formed tooth. ${ }^{4}$ Although its etiology is associated, in most cases, to trauma in the deciduous dentition, 2,18,29 factors such as abnormal development of the root due to the presence of cysts or adjacent tumors; 5,18 the development of the ectopic tooth germ and hereditary factors, may be associated with such anomaly. ${ }^{15,26}$

According to the literature, root dilaceration is relatively rare, with a prevalence of approximately 1 to $4.9 \%$ for all dental groups. ${ }^{10,16,28}$ However, no studies were found related to root dilaceration restricted to the incisor region, subject-matter of this work, which showed a prevalence of $1.03 \%$.

Santana, Consolaro and Tavano ${ }^{21}$ observed root dilacerations in 19 central incisors and upper permanent lateral out of the 203 teeth affected with this anomaly, with a prevalence of $0.3 \%$ for the incisors. Malcic et $\mathrm{al}{ }^{16}$ observed a prevalence of $1.01 \%$ of root dilaceration in incisors while examining all teeth.

From the root dilaceration observed, the group most frequently affected was the upper lateral incisors $(78 \%)$, followed by lower lateral (14.6\%), upper central (4.9\%) and lower central (2.5\%) 
agreeing with Erlich, Pereira and Panella ${ }^{10}$ by claiming that from all incisors, the upper lateral were the most affected by dilaceration (22.1\%). However, the results of Silva Filho et $\mathrm{al}^{25}$ contradict those in this study, since the central incisors were the most affected (70.6\%), followed by the lateral (20.6\%) and lower incisors $(8.8 \%)$. It is noteworthy that Santana, Consolaro and Tavano ${ }^{21}$ did not observe root dilaceration in lower incisors, studying 6,443 permanent incisors.

The root dilaceration in incisors was more frequent in the maxilla (82.8\%) than in the mandible $(17.2 \%)$. This value was similar to the results found by Malcic et $\mathrm{al}^{16}$ (83.3\% of the cases studied in maxillary periapical radiographs and $72.2 \%$ of maxillary cases, in panoramic films); and Erlich, Pereira and Panella ${ }^{10}$ (58.1\%). Perhaps, this result is a consequence of trauma factor, affecting with some frequency the maxillary region of children in the deciduous dentition phase and especially the upper incisors, due to its location. ${ }^{2}$

Regarding gender, root dilaceration was more frequent in males (65.8\%) than in females (34.2\%). Opposed to these results, Erlich, Pereira and Panella, ${ }^{10}$ Vicci and Capeloza ${ }^{28}$ reported this to occur more in females than in males, $68.88 \%$ and $59.6 \%$ of the samples, respectively.

The most prevalent type of dilaceration in this sample was the mild one $(73.1 \%)$, followed by moderate $(17 \%)$ and severe $(9.7 \%)$ confirming the findings of Santana, Consolaro and Tavano, ${ }^{21}$ Ehrlich, Pereira and Panella ${ }^{10}$ who observed, respectively, that $69.4 \%$ and $84.5 \%$ were dilacerations of the mild type, $27.9 \%$ and $13.8 \%$ moderate and $2.9 \%$ and $1.66 \%$ severe.

As for the root third where they were located, $90.2 \%$ of dilacerations were in the apical third, which agrees with the results of Malcic et al; ${ }^{16}$ Santana, Consolaro and Tavano ${ }^{21}$ and Erlich, Pereira and Panella. ${ }^{10}$ In the middle and apical third, the prevalence was $7.3 \%$ and $2.4 \%$, confirming the findings of Malcic et $\mathrm{a}^{16}$ of $13 \%$ and $2.3 \%$ respectively. Santana, Consolaro and Tavano, ${ }^{21}$ studying 19 upper incisors with root dilaceration, did not observe a curvature in the cervical third.

Regarding the direction of the anomaly, the roots were distally directed in $95.1 \%$ of the incisors, in agreement with the study of Santana, Consolaro and Tavano ${ }^{21}$ who observed that $89 \%$ of the roots were focused to distal.

The root dilaceration of the mild type, involving most of the sample, usually does not result in tooth loss during orthodontic mechanics, not even in complications during endodontic or surgical treatment. ${ }^{16}$ In cases of root dilaceration of severe type, there is a need for specialized follow up and greater clinical and radiographic control during orthodontic mechanics, especially in traction, resulting in the need for root canal treatment and apicectomy to finish traction and obtain a favorable ${ }^{6}$ prognosis, in some cases. Thus, the patient in the beginning of treatment must be alerted to the need for further treatment, or even the possibility of tooth loss depending on the position where the tooth is located, while in the mild type of root dilaceration this possibility does not exist. ${ }^{16}$

The panoramic and periapical radiographs are important tools and widely used by clinicians in daily practice as a complementary test for diagnosis. In the case of root dilacerations, these exams have a fundamental role in diagnosis, as well as to obtain the prevalence studies. As in the study by Malcic et $\mathrm{al}^{16}{ }^{16}$ periapical and panoramic radiographs were evaluated in this study to determine the prevalence of root dilaceration.

Faerman et $\mathrm{al}^{11}$ emphasized that early diagnosis of the dilaceration involves performing radiographs on all children in the mixed dentition phase, with a good clinical examination, avoiding functional, esthetic, phonetic and psychological problems to patients.

In cases where there is the need for surgery for orthodontic traction, extraction or endodontic treatment, of a dilacerated tooth, it is essential to obtain the position of the unerupted tooth, for surgical planning and evaluation of degree of difficulty, thus avoiding unexpected events during surgery. ${ }^{6,9,11,16}$

\section{CONCLUSIONS}

According to the methodology used and results obtained in the present work, root dilaceration of incisors, although not very common, is a major anomaly affecting the anterior teeth, with a 
prevalence of $1.03 \%$ of the sample, the lateral incisors are the most affected ones $(92.6 \%)$, particularly higher prevalence in the upper incisors (78.0\%), occurring more in the apical third (90.2\%) and distal direction of the root (95.1\%).
Severe root dilacerations make it more difficult or even prevent any surgical performance, orthodontic and endodontic treatment, compromising the individual's esthetics and function, given the importance of radiographic examination in early diagnosis.

\section{REFERENCES}

1. Andreasen JO, Andreasen FM. Textbook and color atlas of traumatic injures to the teeth. $3^{\text {th }}$ ed. St. Louis: CV Mosby; 1994.

2. Artun J, Behbehani F, Al-Jame B, Kerosuo H. Incisor trauma in an adolescent Arab population: Prevalence, severity, and occlusal risk factors. Am J Orthod Dentofacial Orthop. 2005;128(3):347-52.

3. Brin I, Fuks A, Bassat YB, Zilberman Y. Trauma to primary incisors and its effect on the permanent successors. Pediatric Dent. 1984;6(2):78-82.

4. Casati-Alvares $\mathrm{L}$, Tavano $\mathrm{O}$. Aspectos radiográficos das anomalias dentárias $\mathrm{e}$ maxilares. In: Freitas A, Rosa JE, Souza IF. Radiologia odontológica. 6a ed. São Paulo: Artes Médicas; 2004.

5. Cardoso LC, Miyahara GI, Magro Filho O, Garcia Júnior IR, Soubhia AMP Odontoma combinado associado a dentes não-irrompidos: relato de casos clínicos. Rev Odontol Araçatuba. 2003;24(2):47-51.

6. Chew MT, Ong MM. Orthodontic-surgical management of an impacted dilacerated maxillary central incisor: a clinical case report. Pediatric Dent. 2004;26(4):341-4

7. Chohayeb AA. Dilaceration of permanent upper lateral incisors: frequency, direction and endodontic treatment implication. Oral Surg. 1983;55(5):519-20.

8. Costa LRRS, Correa MSNP, Ribeiro RA. Traumatismo na dentição decídua. In: Correa MSNP. Odontopediatria na primeira infância. São Paulo: Ed. Santos; 1998. p. 527-47.

9. Costa CS, Medeiros MN, Souza APP, Prado C, Aratani M, Parizotto SPCOL, Moselle O. Dilaceração radicular: tratamento cirúrgico e reabilitação estético-funcional do paciente. Rev Bras Cir Implant. 2001:8(29):76-80.

10. Erlich T, Pereira MF, Panella J. Estudo da prevalência da dilaceração radicular, por meio de exame radiográfico periapical, numa amostra populacional da Grande São Paulo. Rev Pós Grad. 2001;8(2):129-37.

11. Faerman K, Campos V, Souchois MWM, Carneiro MAS, Alexandre GC. A Importância do exame radiográfico na dilaceração radicular de incisivos centrais superiores permanentes após traumatismo dentário. JBP: J Bras Odontopediatr Odontol Bebê. 2002:5(26):328-35.

12. Gonçalves SRJ, Santos AA, Oliveira CCC, Dantas Neta EM, Teles CL, Bonjardim RL. Avulsão traumática anterior na dentição decídua. Odontol Clín-Científ. 2004:3(2):111-6.

13. Hernandes MCCO, Goulart MM, Paleckis LGP. Trauma em dentição decídua e suas conseqüências na dentição permanente: relato de caso clínico. Rev EAP/ APCD. 2003 [acesso 2003 Ago 1]. Disponível em: www.apcd.com.br/rev_art. asp?path=REVISTA\&artigo $=33$

14. Laskaris G. Anomalias dentárias In: Atlas colorido de doenças bucais da infância e da adolescência. Porto Alegre; São Paulo: Ed. Santos; 2000. p. 2-35

15. Lin YJ. Treatment of an impacted dilacerated maxillary central incisor. Am J Orthod Dentofacial Orthop. 1999:115(4):406-9.
16. Malcić A, Jukić S, Brzović V, Miletić I, Pelivan I, Anić I. Prevalence of root dilaceration in adult dental patients in Croatia. Oral Surg Oral Med Oral Pathol Oral Radiol Endod. 2006;102(1):104-9.

17. McNamara T, Wolfe SN, McNamara CM. Controle ortodôntico de um incisivo central superior dilacerado com uma seqüela incomum. Rev Dental Press Ortod Ortop Facial. 1998;3(6):26-8.

18. Neville BW, et al. Alterações dentárias de desenvolvimento. In: Neville BW, Damm DD, Allem CM, Bouquot JE. Patologia oral e maxilofacial. 2ª ed. Rio de Janeiro: Guanabara-Koogan; 2004. p. 68-103.

19. Regezi JA, Sciubba JJ. Anomalias dentárias. In: Patologia bucal: correlações clínicopatológicas. Rio de Janeiro: Guanabara Koogan; 1991. p. 341-62.

20. Rodrigues TL. Tratamento orto-cirúrgico do incisivo central superior incluso com coroa invertida e dilaceração radicular: um novo enfoque [dissertação]. Rio de Janeiro: Universidade Federal do Rio de Janeiro; 2001.

21. Santana EJB, Consolaro A, Tavano O. Determinação da prevalência e estudo morfológico da dilaceração radicular. Rev Fac Odontol UFBA. 19921993;12(13):40-52

22. Santos SH. Dilaceração radicular, tratamento ortodôntico e estético - relato de um caso clínico. SOTAU: Rev Virtual Odontol. 2007;1(17) [Acesso 2007 Ago 7]. Disponível em: http://sotau.sind.googlepages.com/ SotauRevVirtOdont20071pag17a22.pdf.

23. Shafer WG, Hine MK, Levy BM. Distúrbios de desenvolvimento das estruturas bucais e parabucais. In: Tratado de Patologia bucal. Rio de Janeiro: Guanabara Koogan; 1987. p. 2-79.

24. Schneider SW. A comparison of canal preparations in straight and curved root canals. Oral Surg. 1971;32(2):271-5.

25. Silva Filho OG, Dias JB, Cavassan AO, Carvalho IMM, Navarro MFL, Schuckar M Distúrbios irruptivos na região ântero-superior: abordagem multidisciplinar. Rev Dental Press Ortod Ortop Maxilar. 1997;2(6):49-62.

26. Tanaka E, Hasegawa T, Hanaoka K, Yoneno K, Matsumoto E, Dalla-Bona D, et al. Severe crowding and a dilacerated maxillary central incisor in an adolescent. Angle Orthod. 2006;76(3):510-8.

27. Vasconcellos RJH, Oliveira DM, Nogueira RVB, Maciel AP; Cordeiro MC. Trauma na dentição decídua: enfoque atual. Rev Cir Traumatol Buco-Maxilo-Facial. 2003;3(2):17-24

28. Vicci JG, Capelozza ALA. Incidência de lesões dentárias e ósseas evidenciadas através de radiografia panorâmica. Rev Fac Odontol Lins. 2002;14(2):43-6.

29. Viegas CMS, Godoi PFS, Ramos-Jorge ML, Ferreira EF, Zarzar PMPA. Traumatismo na dentição decídua: prevalência, fatores etiológicos e predisponentes. Arq Odontol. 2006;42(4):257-336 